GRADIATION\&APPLICATIONS

ISSN 2466-4294 (online) | rad-journal.org

Vol. 3 | Issue 2 | pp. 64-70, 2018

doi: 10.21175/RadJ.2018.02.012

Invited review paper

\title{
ENVIRONMENTAL RADIATION MONITORING AND RADIOLOGICAL ASSESSMENTS AT THE IRT-SOFIA NUCLEAR SITE*
}

\author{
Kiril Krezhov ${ }^{1,2^{* *}}$, Tzvetana Nonova², Alexander Mladenov², Dobromir Dimitrov² \\ ${ }^{1}$ Frank Laboratory of Neutron Physics, Joint Institute for Nuclear Research, Dubna, Russia \\ ${ }^{2}$ Institute for Nuclear Research and Nuclear Energy, Bulgarian Academy of Sciences, Sofia, Bulgaria
}

\begin{abstract}
We report on the findings from the short- and long-term environmental monitoring in selected control points within the IRT-Sofia nuclear site, which is an important part of the radiation and radiological surveillance during the operation and maintenance of the facilities at the Nuclear Scientific Experimental and Educational Centre (NSEEC) of the Institute for Nuclear Research and Nuclear Energy. Consideration is given to experimental evidence and analyses covering the last 8 years and the overlap issues with environmental data accumulated from 1961 to 2008 are commented upon.
\end{abstract}

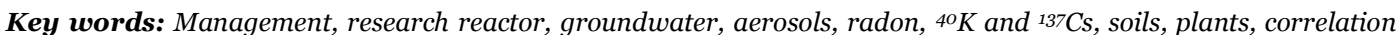
analysis, transfer factors

\section{INTRODUCTION}

In accordance with the Bulgarian and European legislation, the environmental monitoring program at the nuclear facility shall contain radiation measurements of the environment and assessments of produced radioactive substances in order to determine the volume, nuclide concentration, and possible origin of radioactive substances in the environment. [1-3] The assessment or control of exposure to ionizing radiation and its impact on humans and the environment is the aim. To draw detailed conclusions, the observations shall be conducted regularly and over a long period of time (long-term monitoring). [4-6]

The radiation control of the workplace and monitoring of the radiological status at the Nuclear Scientific Experimental and Education Centre (NSEEC) with the research reactor IRT at the Institute for Nuclear Research and Nuclear Energy (INRNE) is achieved by individual control means [7] and a set of stationary and mobile autonomous units [8-10] providing monitoring of reactor facility workplaces and its surroundings by a continuous measurement of radiation background and aerosols in combination with the analyses of alpha, beta, and gamma emitters in randomly and purposely taken smears and environmental samples. The aim is to specify the radionuclide contents in the air (aerosols), water (groundwater and rainfall), soil, and selected plants (bioindicators) at the site (see Figure 1).

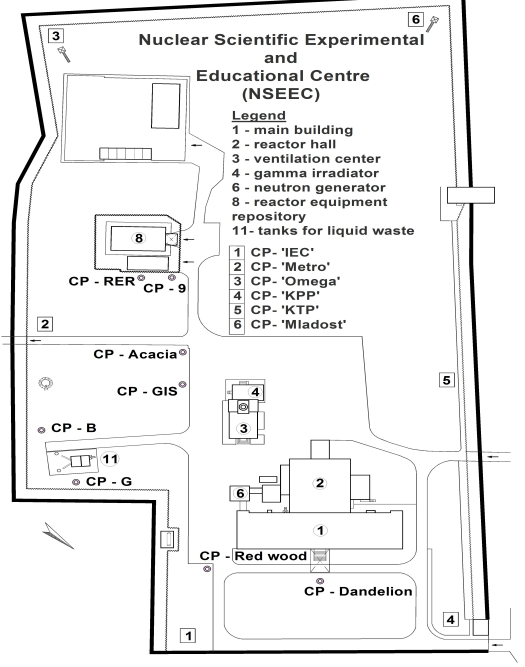

Figure 1. Schematic view of the NSEEC site with marked locations of radiation monitoring points

This article gives an overview of the environmental impact assessment activities on the IRT-Sofia nuclear site. We consider the last results for the 2014-2017 period and previous findings from the short- and longterm studies of the radiation risks to people and to the environment that may arise from the use of radiation and radioactive materials within the site, including the partial dismantling activities in 2009-2011 related to

\footnotetext{
* This paper was presented as an invited lecture at the Sixth International Conference on Radiation and Applications in Various Fields of Research (RAD 2018), Ohrid, Macedonia, 2018.

*kiril.krezhov@gmail.com
} 
the IRT-Sofia reactor refurbishment project and after their accomplishment. The surveys trace contaminant levels and reveal trends in the changes in the concentrations of harmful substances, including radon, and the effects and causes for such changes.

\section{BASIC PRINCIPLES AND METHODS}

The environmental radiation monitoring at the NSEEC is carried out in accordance with the specially developed General Program (GP) [9] for radiation monitoring by compiling a set of technical and organizational resources and activities related to the implementation of the ALARA principle and the European and national legislation. [1-6]

The NSEEC is equipped with a highly efficient integrated automatic Radiation Monitoring System (RMS) for technological and environmental monitoring. [8] Based on the integrated RMS, the GP allows the real-time monitoring and control of radiation parameters in the controlled areas and provides for a high level of radiation protection of the NSEEC staff, users and visitors of its facilities as well as of the site environment. The guiding idea is that the use of measured data (historical records) is preferable to using models in a dose reconstruction project.

Environmental monitoring with the RMS external system includes monitoring of the dose rate, alpha and beta activity, radon activity, Po-218, Po-214, Po-212 activity, and the gamma control of vehicles. The technological control of reactor gases includes an alpha/beta particulate monitor, iodine monitor, noble gases monitor, and a stack flow monitor. All RMS detectors are connected to the RAMSYS server. They have online (real-time) visualization in two workstations with the RAMVISION software. [8, 9]

Gamma background is measured continuously in six control stations (KPP, KTP, Mladost, IEC, Omega, and Metro) using GIM-204 gamma-radiation monitors. All gamma monitors are connected and are part of the RMS. The GIM-204 employs a silicon detector and operates in the range (IEC 532) from $10^{-6}$ to $1 \mathrm{~Sv}^{-1}{ }^{-1}$ for energies ranging from $60 \mathrm{keV}$ to $3 \mathrm{MeV}$. [8]

Three ABPM 201L aerosol monitors are located in three posts selected according to the wind rose at the site. The height of ambient air sampling nozzles is fixed at $1.70 \mathrm{~m}$ above ground to favor an absorbed-dose evaluation. Radon results are complemented with planned outdoor radon concentration measurements by a mobile autonomic ABPM 203-M unit. [10]

The ABPM 201L (dual large area silicon detector; MILLIPORE filter FSLW2) measure alpha, beta, and gamma radiation. Typical energy windows are 2-10 $\mathrm{MeV}$ for alpha, and $80 \mathrm{keV}$ to $2.5 \mathrm{MeV}$ for beta and gamma. The measurement range is $1.0 \times 10^{-2}-3.7 \times 10^{6}$ Bq. ${ }^{-3}$ for alpha and 1.0-3.7 x $10^{6}$ Bq.m ${ }^{-3}$ for beta.

The assessment of the radioecological status of the IRT environment based on the taken samples and the determination of the radionuclide contents is carried out monthly in a grid of pre-selected observation control points (CP). $[8,11]$. The purpose of the sampling is to obtain a small and informative portion of the object undergoing examination and to provide samples which adequately describe the properties of the entire system. Sampling locations were selected close to the points where the maximum exposure or deposition is expected. The monitoring records were taken at the same location for the year-by-year comparison of the results.

Total $\alpha / \beta$ activity and $\gamma$ radionuclide content were analyzed in aerosols, soil collected from two CPs (RER - Reactor equipment repository and GIS - Gamma irradiation system), underground water from three CPs, rainfall waters (rainy and snowy), and two bioindicator plant species - redwood (Sequoiadendron giganteum) and acacia (Robinia pseudoacacia). [10,11]

Both plant species are perennial but they differ by their life cycle and maximum of development as well as by their accumulation capability. The perennial plant species are widely distributed in various terrestrial ecosystems and provide one of the first signals for changes in the ecological status of the environment. They are very suitable as bioindicators for purposes of long-time environmental monitoring and their use provides an essential method for measuring the bioavailability of specific contaminants like radionuclides.

The total $\beta$ activity analysis was performed as an initial screening tool to determine whether or not more detailed isotopic analyses are warranted. [12] In this study, the data for the total beta activity were obtained only for a screening assay and for checking whether the measured values fall within the range previously measured by us. To determine the total $\beta$ activity, the water samples were evaporated to dryness using a sand bath and an infrared lamp. Soil and plants were measured after their cleaning from mechanical impurities, drying, milling (plants) or fractionation (soil), and homogenizing and ashing in a muffle furnace at $500^{\circ} \mathrm{C}$. For gamma spectrometry measurements, the samples were only dried and mechanically cleaned. After grinding them to a fine powder, the homogenized soil and plant samples were loaded into special $50-\mathrm{cm}^{3}$ hermetic containers for gamma spectrometry. The water samples were sealed in Marinelli (1000 ml) standard vessels. Aerosol filters were measured directly without preconditioning.

The total $\beta$ activity of water, soil and plant specimens was measured by a UVJ-01 universal measuring device with a Geiger detector with an efficiency of $0.23 \mathrm{cps} \mathrm{Bq}{ }^{-1}$ for ${ }^{90} \mathrm{Sr} / 9^{\circ} \mathrm{Y}$ (MK-30 Measuring Chamber) and a background of $\leq 2 \mathrm{cps}$ (VF s.r.o. Žilina, http://www.vf.cz). The total $\alpha / \beta$ activity in aerosol filters was measured by Multi-Detector Systems PIC-MDS-8 (Protean Instr. http://www.proteaninstrument.com), at a background of $0.03-0.07 \mathrm{cpm}$ for $\alpha$ and $0.4-0.7 \mathrm{cpm}$ for $\beta$ activity. The efficiency varies between 35 and $55 \%$, depending on the energy and geometry of the sources.

The gamma spectrometry measurements were made with a HPGe-GMX 50P4 Coaxial Photon Detector System with a Beryllium window (Ortec) with an energy resolution of $2.3 \mathrm{KeV}$ at $1332 \mathrm{KeV}\left({ }^{6 \circ} \mathrm{Co}\right)$ and a counting efficiency of $50 \%$.

All data were assessed by detailed descriptive statistics for studying correlations. [13] 
K. Krezhov et al., Environmental radiation monitoring and radiological assessments..., Rad. Applic., 2018, 3, 2, 64-70

\section{RESULTS}

For the purposes of radiation monitoring at the IRT site and in accordance with the GP in the 2014-2017 period, more than 700 samples (water, soil, and plants) were collected and more than 1200 analyses were carried out. The RMS in continuous operation in an ordinary situation recorded data for $\alpha / \beta$ activity and radon content in the air in the interval of one hour.

\subsection{Gamma background control}

Gamma background was measured continuously in six CPs at the IRT area in order to check the conformity to the limits of allowed discharges for the early detection and evaluation of eventual releases, their consequences to the surroundings of people's workplaces and to the environment. The obtained data show that the mean daily values for the 2014-2017 period range from 0.081 (CP 'Mladost', March 2015) to 0.124 mSv.h-1 (CP 'Metro', November 2016). These data are slightly lower than the one we obtained for the 2011-2013 period (0.10-0.13 mSv.h $\left.{ }^{-1}\right)$. [11] The minimum of $0.082 \mathrm{mSv} \cdot \mathrm{h}^{-1}$ was registered in February 2015 (CP 'Mladost') and the maximum of $0.101 \mathrm{mSv}^{-1} \mathrm{~h}^{-1}$ in November 2016 (CP 'KTP'). Figure 2 gives the mean annual values obtained for the 2014-2017 period and shows that all data vary within a narrow range of 0.096-0.101 $\mathrm{mSv} \mathrm{h}^{-1}$.

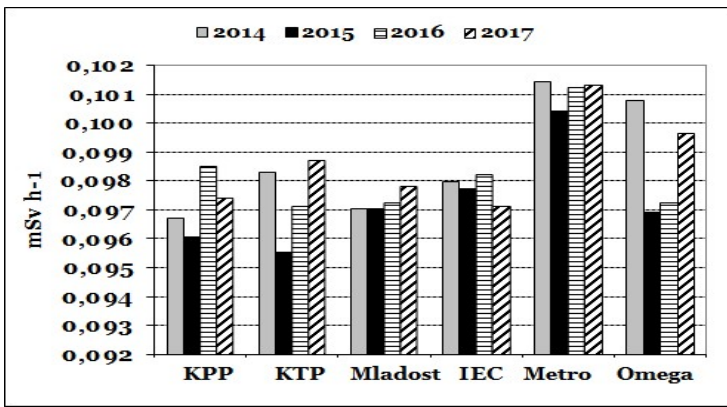

Figure 2. Gamma background levels in $\mu$ Sv.h ${ }^{-1}$

The lowest values were recorded at CP 'KPP' (2014, 2015) and at CP 'KTP' (2015) while the highest were measured at CP 'Omega' (2014) and CP 'Metro' (2015, 2017). All the results indicate a natural gamma background in the area and evidence an absence of radiation contamination.

\subsection{Control of aerosols and radon}

Data registered by ABPM 201L aerosol monitors show that the mean daily beta activity in the area during the whole studied period was 1.10 Bq. ${ }^{-3}$. Within the day, the mean values for 1 hour usually varied between 1.00 and 1.74 Bq. ${ }^{-3}$. The recorded mean daily alpha activity in aerosols at the site was 3 $\mathrm{mBq} \cdot \mathrm{m}^{-3}$. The average alpha activity per hour varied in the interval 1-5.7 mBq. ${ }^{-3}$.

Background radon levels vary widely from one $\mathrm{CP}$ of the site to the next. The mean radon levels registered for one hour at the IRT site CPs vary from 0.100 to $0.115 \mathrm{~Bq} \cdot \mathrm{m}^{-3}$. The mean daily value measured during the last 4 years is $0.101 \mathrm{~Bq} . \mathrm{m}^{-3}$. Somewhat higher levels of radon concentration were recorded mainly in the afternoon hours of summer [10]. The measured radon concentration in the area close to the reactor building is $0.28 \pm 0.18 \mathrm{~Bq} \mathrm{~m}^{-3}$.

\subsection{Total beta activity water control}

The total beta activity in the groundwater samples collected from three important control points (CP-B, $\mathrm{CP}-\mathrm{G}$ and $\mathrm{CP}-9$ ) located next to the areas exposed to radiation (underground tanks for sewage waters and RER) during the last four years varies from 0.25 Bq. $\mathrm{L}^{-1}$ (CP-G, in July 2014) to 0.71 Bq.L-1 (CP-G, in March 2017). Figure 3 illustrates the mean monthly contents of beta radionuclides in groundwater.

It is to note that the mean values and concentration variation intervals for the 2011-2013 period were 0.41 Bq.L. $L^{-1}\left(0.24-1.39\right.$ Bq.L. $\left.{ }^{-1}\right)$ at CP-B, 0.43 Bq.L-1 (0.280.81 Bq. $\left.\mathrm{L}^{-1}\right)$ at CP-G and 0.35 Bq.L ${ }^{-1}\left(0.24-0.52\right.$ Bq. $\left.\mathrm{L}^{-1}\right)$ at $\mathrm{CP}-9 .[10,11]$ These data show that all values vary in wider intervals and the highest recorded values are significantly higher than the data established for the 2014-2017 period.

The mean values for underground water for the whole period from 2014 to 2017 are very close -0.48 Bq. $\mathrm{L}^{-1}$ for CP-B, 0.49 Bq.L-1 for CP-G, and 0.45 Bq.L-1 for $\mathrm{CP}-9$. The data (mean value $\pm \mathrm{SD}$ and concentration range) presented in Table 1 show a slight increase in the mean annual value in waters at CP-B and CP-G and relatively constant mean values at $\mathrm{CP}-9$.

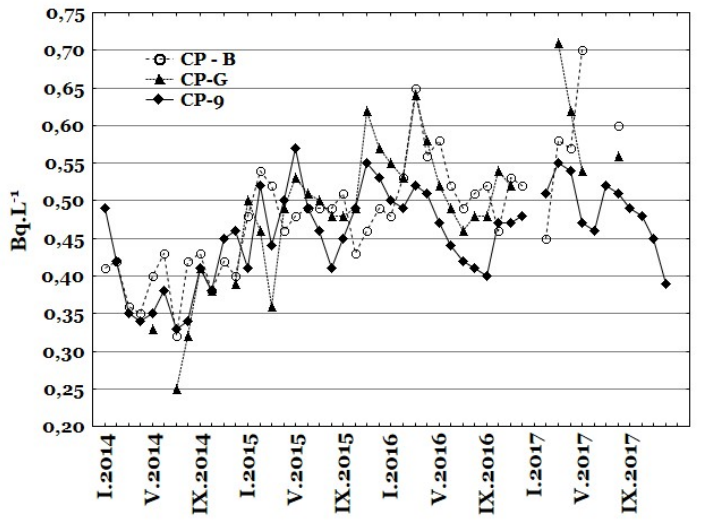

Figure 3. Mean monthly beta activity levels in underground water for the 2014-2017 period in Bq.L $\mathrm{L}^{-1}$

Table 1. Mean annual total beta activity in underground water collected from CP-B, CP-G and CP-9

\begin{tabular}{|c|l|l|l|}
\hline Year & $\begin{array}{l}\text { CP-B } \\
\text { Mean } \pm \text { SD } \\
\text { (Range) }\end{array}$ & $\begin{array}{l}\text { CP-G } \\
\text { Mean } \pm \text { SD } \\
\text { (Range) }\end{array}$ & $\begin{array}{l}\text { CP-9 } \\
\text { Mean } \pm \text { SD } \\
\text { (Range) }\end{array}$ \\
\hline 2014 & $\begin{array}{l}0.39 \pm 0.04 \\
(0.32-0.43)\end{array}$ & $\begin{array}{l}0.35 \pm 0.06 \\
(0.25-0.41)\end{array}$ & $\begin{array}{l}0.39 \pm 0.05 \\
(0.33-0.49)\end{array}$ \\
2015 & $\begin{array}{l}0.49 \pm 0.03 \\
2016\end{array}$ & $\begin{array}{l}0.50 \pm 0.06 \\
(0.43-0.54)\end{array}$ & $\begin{array}{l}(0.36-0.62) \\
(0.41-0.54\end{array}$ \\
& $\begin{array}{l}0.53 \pm 0.05 \\
2017\end{array}$ & $\begin{array}{l}0.52 \pm 0.05 \\
(0.46-0.65)\end{array}$ & $\begin{array}{l}(0.46-0.64) \\
(0.46-0.04\end{array}$ \\
& $\begin{array}{l}0.58 \pm 0.09 \\
(0.45-0.70)\end{array}$ & $\begin{array}{l}0.61 \pm 0.08 \\
(0.54-0.71)\end{array}$ & $\begin{array}{l}0.49 \pm 0.05 \\
(0.39-0.55)\end{array}$ \\
\hline
\end{tabular}


K. Krezhov et al., Environmental radiation monitoring and radiological assessments..., Rad. Applic., 2018, 3, 2, 64-70

The groundwater data shows that the level of beta activity comes exclusively from natural radionuclides (mainly nuclides of the $U$ and Th chains), which enter the composition of the surrounding geological matrix.

The data for total beta activity in rain and snow waters during the 2014-2017 period ranged between 0.30 and 1.18 Bq.L $\mathrm{L}^{-1}$ with a minimum on February 7 , 2017 (snow) and a maximum on August 30, 2014 (rain). Both limit values are lower than the corresponding data obtained for the 2011-2013 period - 46 Bq.L - $^{-1}$ (registered on February 24, 2013) and 2.27 Bq.L $\mathrm{L}^{-1}$ (registered on August 11, 2011).

Figure 4 presents the mean monthly total beta activity in rainfall. All the data are within the limits of 0.33 and 1.14 Bq.L $\mathrm{L}^{-1}$, registered in August 2016 and November 2014, respectively. Table 2 shows the mean annual values.

Table 2. Mean annual total beta activity in rainfalls (Bq. $\left.\mathrm{L}^{-1}\right)$

\begin{tabular}{|l|l|l|}
\hline Year & Mean \pm SD & Range \\
\hline 2014 & $0.92 \pm 0.19$ & $0.57-1.14$ \\
2015 & $0.72 \pm 0.14$ & $0.47-0.97$ \\
2016 & $0.54 \pm 0.14$ & $0.33-0.79$ \\
2017 & $0.52 \pm 0.05$ & $0.43-0.60$ \\
\hline
\end{tabular}

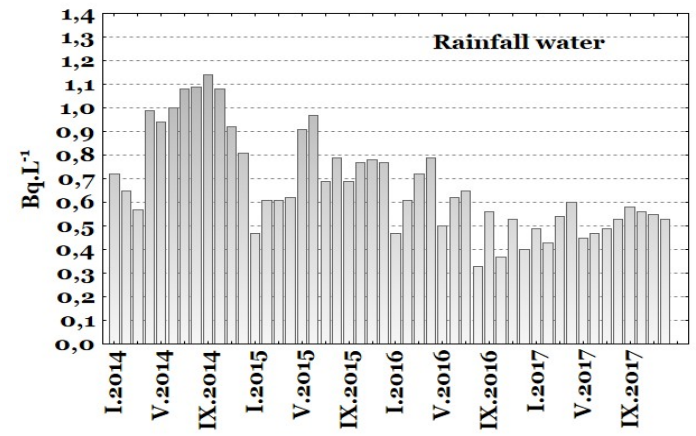

Figure 4. Mean monthly beta activity levels in rainfall water for the 2014-2017 period in Bq. $\mathrm{L}^{-1}$

\subsection{Total beta activity control of soil and plants}

The data obtained for the total beta activity in soil is higher than that measured in plants, which is normal and related to the type of analyzed samples (Figure 5).

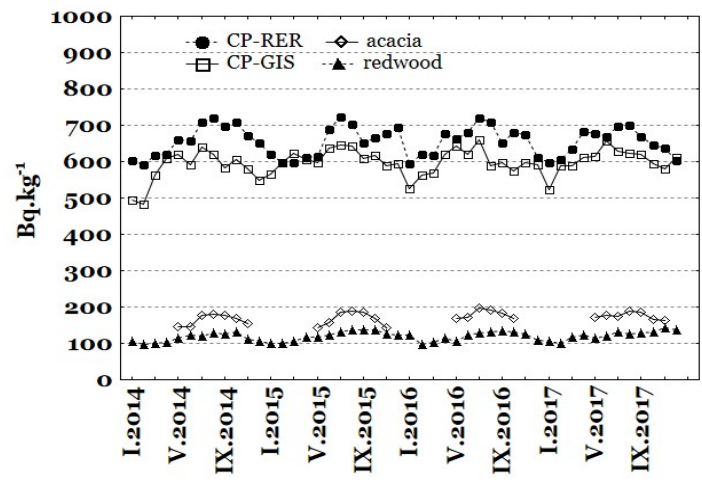

Figure 5. Mean monthly beta activity levels in soil and plants for the 2014-2017 period in Bq.kg-1
Figure 5 makes evident that the mean monthly beta activities of soil vary from 592 to $722 \mathrm{~Bq} \cdot \mathrm{kg}^{-1}$ at CPRER. The lowest value was registered in February 2014 and the highest - in July 2015. The measured values in soil samples from CP-RER during the 2011-2013 period were in the interval of $577-824 \mathrm{~Bq} \cdot \mathrm{kg}^{-1}$. [11] A comparison of the results yields that over the last four years there is a decrease in the upper limit value of about $100 \mathrm{~Bq} \cdot \mathrm{kg}^{-1}$. Data obtained for mean monthly beta activities in soil collected at CP-GIS are lower and vary between 483 (February 2014) and 660 Bq.kg-1 (July 2016). The comparison of the data with those obtained for the 2011-2013 period (505 and 732 Bq.kg1) [11] also shows a decrease of the limit values.

A more comprehensive analysis shows that the minimum values in both CPs were recorded in the winter season, i.e. February (2014). The maximum values were registered in the summer, i.e. July (2015 and 2016). The same tendency was observed for the 2011-2013 period, when the minimum for both CPs (RER and GIS) was recorded in January (2012) and the maximum in July 2011 (RER) and August 2011 (GIS). [11]

All results are within the normal levels for this region range and do not exceed the limits set by the national legislation. Higher values typical for the summer season are probably more due to differences in the environmental conditions and some specific abiotic factors (temperature, light, solar radiation, humidity, etc.) rather than an anthropogenic impact.

Significantly lower are the values for the two plant species. Figure 5 shows a similarity in the beta radionuclide accumulation pattern within one year. There were no extreme values obtained during the four years of observation. Data for beta activities in plant tissues vary from $96 \mathrm{~Bq} \cdot \mathrm{kg}^{-1}$ (February 2016) to 143 Bq.kg-1 (November 2017) for redwood and from 142 Bq.kg-1 (October 2015) to 196 Bq.kg-1 (July 2016) for acacia. The mean annual data are presented in Table 3.

Table 3. Mean annual total beta activity in acacia and redwood samples in Bq.kg-1

\begin{tabular}{|l|l|l|}
\hline Year & $\begin{array}{l}\text { Acacia } \\
\text { Mean } \pm \text { SD } \\
(\text { Range) }\end{array}$ & $\begin{array}{l}\text { Redwood } \\
\text { Mean } \pm \text { SD } \\
\text { (Range) }\end{array}$ \\
\hline 2014 & $164 \pm 15$ & $114 \pm 12$ \\
& $(145-181)$ & $(98-132)$ \\
2015 & $168 \pm 19$ & $121 \pm 14$ \\
& $(142-189)$ & $(100-138)$ \\
2016 & $180 \pm 12$ & $119 \pm 13$ \\
& $(168-196)$ & $(96-134)$ \\
2017 & $175 \pm 11$ & $123 \pm 12$ \\
& $(162-189)$ & $(101-143)$ \\
\hline
\end{tabular}

The values show that the concentration variationss are within a relatively narrow range - from about 27 to $47 \mathrm{~Bq} \cdot \mathrm{kg}^{-1}$ for both tested species. There are no extreme values, but the data analysis shows that the lower limits of acacia beta-radionuclide content are higher than the maximum values obtained for the redwood. These differences are probably due to specific morphological and physiological characteristics of these species.

All the results collected at the IRT site for the beta radionuclide accumulation in redwood and acacia 
K. Krezhov et al., Environmental radiation monitoring and radiological assessments..., Rad. Applic., 2018, 3, 2, 64-70

species are comparable with the data obtained at other areas from known as unpolluted sites. Such evidence is in support to the claim for the absence of some anthropogenic impacts within the IRT site boundaries.

\subsection{Gamma radionuclides in soils and plants}

The ${ }^{40} \mathrm{~K}$ and ${ }^{137 \mathrm{Cs}}$ gamma radionuclides were measured in soils and redwood and the results show that both radionuclide contents are higher in plant samples (Figures 6 and 7). This fact is connected with their function and major role in the metabolic processes in plant organisms. Potassium is an essential nutrient that affects most of the biochemical and physiological processes that influence plant growth and metabolism. [14] Caesium is a chemical analogue of $\mathrm{K}$ and follows a similar pattern of bio-sorption.

Potassium-40 specific activities measured for the 2014-2017 period range from 815 to 1038 Bq.kg-1 in soil and from 1245 to $1786 \mathrm{~Bq} \cdot \mathrm{kg}^{-1}$ in redwood. These results are almost the same as those we obtained for the 2011-2013 period [10, 11] - from 826 to 1046 for soil and from 1211 to $1822 \mathrm{~Bq} \cdot \mathrm{kg}^{-1}$ for redwood. During the studied period $(2014-2017)$ the mean annual values vary in narrow intervals: $996-1013 \mathrm{~Bq} \cdot \mathrm{kg}^{-1}$ (soilRER) and 1455-1477 Bq. kg-1 (redwood). Narrow concentration intervals were also observed for the previous monitoring period - standard deviations are between 20 and $60 \mathrm{~Bq} \cdot \mathrm{kg}^{-1}$.

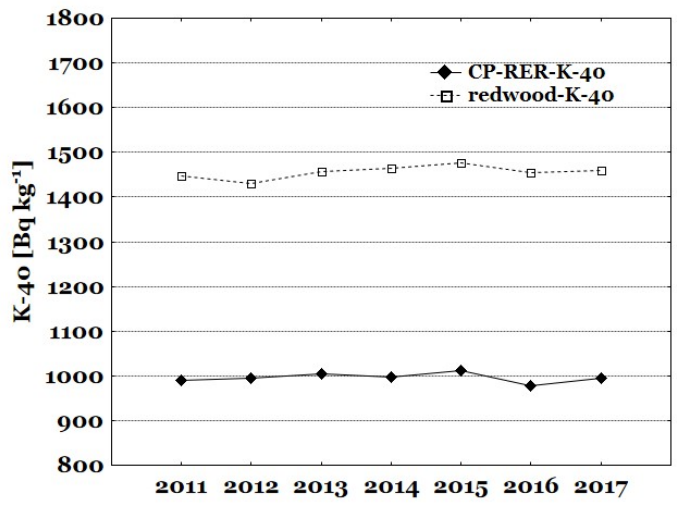

Figure 6. Mean annual ${ }^{40} \mathrm{~K}$ specific activity in soil and redwood samples in Bq.kg-1

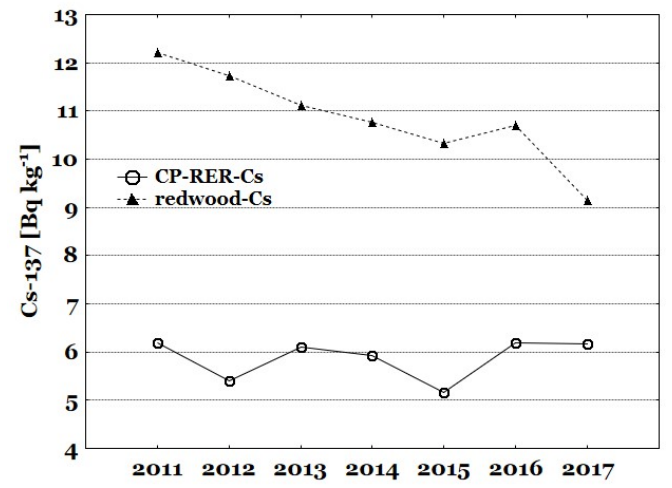

Figure 7. Mean annual ${ }^{137} \mathrm{Cs}$ specific activity in soil and redwood samples in Bq.kg-1
Cesium-137 specific activities measured for the 2014-2017 period range from 3.89 to $8.14 \mathrm{~Bq} \cdot \mathrm{kg}^{-1}$ in soils and from 7.60 to $13.20 \mathrm{~Bq} \cdot \mathrm{kg}^{-1}$ in redwood. These results are similar to the results obtained during the 2011-2013 period [10,11] - from 3.33 to 8.58 for soils and from 9.50 to $19.70 \mathrm{~Bq} \cdot \mathrm{kg}^{-1}$ for redwood. In contrast to lacking a clear seasonal tendency for the change in ${ }^{137} \mathrm{Cs}-$ specific activity, the ${ }^{40} \mathrm{~K}$ data indicate seasonal variations in redwood. The measured activities increase from spring to summer, reach the maximum in late autumn and then decrease.

\subsection{Correlation analysis}

Table 4 summarizes the calculated typical mean values and concentrations variation intervals of the studied parameters in the environmental samples collected in the 2014-2017 period. These data were compared with the data sets collected for water, soil and plants (pine needles, grass, pear, and apple leaves) collected over the IRT site during the previous periods of observation starting from 1961 and the reactor's commissioning, during its operation, and after shutdown of the IRT reactor in July 1988.

Anthropogenic ${ }^{137} \mathrm{Cs}$ radionuclide specific activities measured by Guelev et al [15] in soils are higher (between 25 and 75 Bq.kg-1 before the Chernobyl accident, about $200 \mathrm{~Bq} \cdot \mathrm{kg}^{-1}$ in 1986, and from 20 to $5^{0}$ Bq.kg-1 for 1990-2008) than those obtained by us while the ${ }^{137}$ Cs content in plants is close to our data between 1 and $10 \mathrm{~Bq} \cdot \mathrm{kg}^{-1}$ for the whole period. An exception is the value measured in 1986 (Chernobyl) about $1000 \mathrm{~Bq} \cdot \mathrm{kg}^{-1}$.

Table 4. Typical mean values and concentration ranges of total beta, ${ }^{\circ} \mathrm{K}$, and ${ }^{137} \mathrm{Cs}$-specific activities in environmental samples collected at the IRT site (2011-2017)

\begin{tabular}{|c|c|c|c|}
\hline Sample & $\mathrm{N}^{*}$ & Mean \pm SD & Range \\
\hline \multicolumn{4}{|c|}{ Total beta activity [Bq. $\left.\mathrm{L}^{-1}\right]$} \\
\hline CP-B & 222 & $0.45 \pm 0.17$ & $0.24-1.39$ \\
\hline $\mathrm{CP}-\mathrm{G}$ & 141 & $0.47 \pm 0.11$ & $0.25-0.81$ \\
\hline CP-9 & 240 & $0.41 \pm 0.08$ & $0.24-0.57$ \\
\hline Rainfall & 325 & $0.73 \pm 0.22$ & $0.27-1.16$ \\
\hline \multicolumn{4}{|c|}{ Total beta activity $\left[\mathrm{Bq} \cdot \mathrm{kg}^{-1}\right]$} \\
\hline Soil-RER & 243 & $654 \pm 51$ & $577-824$ \\
\hline Soil-GIS & 243 & $593 \pm 48$ & $483-732$ \\
\hline Acacia & 138 & $175 \pm 15$ & $142-198$ \\
\hline Redwood & 243 & $119 \pm 13$ & $96-146$ \\
\hline \multicolumn{4}{|c|}{${ }^{40} \mathrm{~K}\left[\mathrm{~Bq} \cdot \mathrm{kg}^{-1}\right]$} \\
\hline Soil-RER & 243 & $997 \pm 42$ & $815-1046$ \\
\hline Redwood & 243 & $1457 \pm 153$ & $1211-1822$ \\
\hline \multicolumn{4}{|c|}{${ }^{137} \mathrm{Cs}\left[\mathrm{Bq} \cdot \mathrm{kg}^{-1}\right]$} \\
\hline Soil-RER & 243 & $5.87 \pm 1.18$ & $3.33-8.58$ \\
\hline Redwood & 243 & $10.82 \pm 1.83$ & $7.60-19.70$ \\
\hline
\end{tabular}

Significant positive correlation coefficients (synergistic interaction) for total beta activity were obtained only for the soil RER - soil GIS, soil RER acacia and soil RER - redwood pairs $(r=0.56$, 0.52, and 0.55 , respectively). A significant correlation was observed for ${ }^{\circ} \mathrm{K}$-specific activity and total beta activity levels in redwood $(\mathrm{r}=0.63)$. The registered correlations are significant at $p<0.05$. These correlation coefficients are different from the unit and therefore 
K. Krezhov et al., Environmental radiation monitoring and radiological assessments..., Rad. Applic., 2018, 3, 2, 64-70

the correlation dependence is not clearly expressed, meaning that the variables are related but with weak functional dependence.

For the investigation of the soil-to-plant

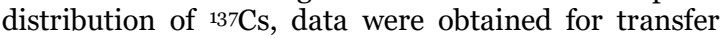
factors (TF) by measuring the radiocaesium specific activity in plant species Taraxacum officinale (dandelion - cosmopolitan, widely distributed proven bio-monitor) and soil samples collected from the same place. The data are displayed in Table 5 .

Table 5. ${ }^{137}$ Cs-specific activity values and TFs (Bq. $\mathrm{kg}^{-1}{ }^{137} \mathrm{Cs}$ in plant vs. Bq.kg-1 ${ }^{-137 C s}$ in soil) obtained for Taraxacum officinale plant species

\begin{tabular}{|c|c|c|c|}
\hline Year & $\begin{array}{l}{ }^{137} \mathrm{Cs} \text { in plant } \\
{\left[\mathrm{Bq} \cdot \mathrm{kg}^{-1}\right]}\end{array}$ & $\begin{array}{l}{ }^{137} \mathrm{Cs} \text { in soil } \\
{\left[\mathrm{Bq} \mathrm{kg}^{-1}\right]}\end{array}$ & TF \\
\hline 2011 & $0.90 \pm 0.08$ & $7.92 \pm 0.6$ & 0.11 \\
\hline 2012 & $1.42 \pm 0.11$ & $7.74 \pm 0.61$ & 0.18 \\
\hline 2013 & $1.23 \pm 0.09$ & $8.12 \pm 0.73$ & 0.15 \\
\hline 2014 & $0.88 \pm 0.07$ & $6.74 \pm 0.55$ & 0.13 \\
\hline 2015 & $0.96 \pm 0.07$ & $5.92 \pm 0.52$ & 0.16 \\
\hline 2016 & $1.15 \pm 0.09$ & $7.60 \pm 0.64$ & 0.15 \\
\hline 2017 & $0.93 \pm 0.08$ & $8.23 \pm 0.72$ & 0.11 \\
\hline
\end{tabular}

Transfer factors were calculated for the periods of maximum vegetation of the studied species (springsummer). The TFs are relatively constant during the last seven years and varied between 0.11-0.18. These values are in good agreement with those commonly reported. [16, 17]

The lesser variability associated with Cs-137 plant concentrations may be partly explained by the ability of plant species to physiologically regulate the uptake of mineral elements. An integrative effect can also be expected due to the larger area of radionuclide uptake through their root systems than the soil sample. [18]

In summary, the results we have presented here are within the range of normal and most frequently published during the last 10 years regarding values obtained for water, soils and plants collected from different Bulgarian regions. [19-21]

\section{CONCLUSION}

The elaborated long-term radiation monitoring and radiological observations of the IRT-Sofia nuclear site allow obtaining accurate information for the typical levels and concentration ranges of various important parameters during the 1961-2017 period and give comprehensive evidence that all the activities at the site, including partial reactor decommissioning have been accomplished safely for the personnel and without measurable radiation consequences for the environment.

Acknowledgements: The authors thank the NSEEC colleagues for helpful discussions. KK would like to thank Professor G. Ristic, convener of the RAD conference series, for the kind invitation to present this overview work to the attention of experts and a broader audience with interests in the field of protection and preservation of the environment. This study was partially supported by the Bulgarian National Science Foundation under Grant DNo8/4.

\section{REFERENCES}

1. Агенция за ядрено регулиране. (28.6.2002). Закон за безопасно използване на ядрената енергия. (Nuclear Regulatory Agency. (Jun. 28, 2002). Act on the Safe Use of Nuclear Energy.)

Retrieved from: http://www.bnra.bg/bg/documents/le gislation/laws/zbiae-2018.pdf;

Retrieved on: Jan. 1, 2018

2. Агенция за ядрено регулиране. (14.2.2018). Наредба за радиационна защита. (Nuclear Regulatory Agency. (Feb. 14, 2018) Regulation on radiation protection.)

Retrieved from: http://www.bnra.bg/bg/documents/le gislation/regulations/merged18p20-pr1234.pdf; Retrieved on: Jan. 23, 2018

3. Radiological monitoring of the environment of a nuclear facility, STUK Guide YVL C.7/19, Radiation and nuclear safety authority, Helsinki, Finland, 2016.

Retrieved from: https://www.finlex.fi/data/normit/430 21/YVL C.7e.pdf;

Retrieved on: Feb. 10, 2018

4. Monitoring the Discharge of Radioactive Substances from Research Reactors, KTA 1507 (2017-11), Nuclear Safety Standards Commission, Salzgitter, Germany, 2017.

Retrieved from: http://www.ktags.de/e/standards/1500/1507 engl 2017_11.pdf; Retrieved on: Feb. 10, 2018

5. Environmental and Source Monitoring for Purposes of Radiation Protection. IAEA Safety Standards series No. RS-G-1.8, IAEA, Vienna, Austria, 2005, pp. 9 - 101. Retrieved from: https://www-

pub.iaea.org/MTCD/publications/PDF/Pub1216 web. pdf;

Retrieved on: Aug. 22, 2005

6. Safety of Research Reactors, IAEA Safety Standards series No. SSR-3, IAEA, Vienna, Austria, 2016, pp. $5-108$.

Retrieved from: https://www-

pub.iaea.org/MTCD/publications/PDF/P1751_web.pdf Retrieved on: Nov. 7, 2016

7. D. Stankov et al., "Individual Dosimetric Control and Monitoring of the Working Environment at the Nuclear Site IRT - Sofia," in Proc. European Medical Physics and Engineering Conference (EMPEC), Sofia, Bulgaria, 2012, pp. $354-359$

Retrieved from: http://bitu.upatras.gr/index.php/book s-and-conference-proceedings/;

Retrieved on: Oct. 13, 2012

8. A. Mladenov et al., "Possibilities of automatic radiation monitoring system in Nuclear Scientific Experimental and Educational Centre," in Proc. $2^{\text {nd }}$ Nat. Congress Phys. Sci. \& 41st Nat. Conf. Phys. Education, Sofia, Bulgaria, 2013, pp. $1-6$.

9. A. Mladenov et al., "Radiation Monitoring Program at Nuclear Scientific Experimental and Educational Center IRT- Sofia," in Proc. European Medical Physics and Engineering Conference (EMPEC), Sofia, Bulgaria, 2012, pp. $354-359$.

10. A. Mladenov, K. Krezhov, "Radon concentration measurements at the IRT-Sofia research reactor site," Radiation \& Applications, vol. 3, no. 1, pp. $52-58$, Apr. 2018.

DOI: 10.21175/RadJ.2018.01.010

11. T. Nonova et al., "Radiological assessment of the IRT Sofia site for the period January 2011 - June 2013," in Proc. $2^{\text {nd }}$ Nat. Congress Phys. Sci. \& 41st Nat. Conf. Phys. Education, Sofia, Bulgaria, 2013, pp. $1-7$. 
K. Krezhov et al., Environmental radiation monitoring and radiological assessments..., Rad. Applic., 2018, 3, 2, 64-70

12. A. Mladenov, D. Stankov, T. Nonova, K. Krezhov, "Radiation protection, radioactive waste management and site monitoring at the Nuclear Scientific Experimental and Educational Centre IRT-Sofia at INRNE - BAS” Rad. Prot. Dosim., vol. 162. no. 1-2, pp. $176-181$, Nov. 2014.

DOI: $10.1093 / \mathrm{rpd} / \mathrm{ncu} 254$

PMid: 25071246

13. STATISTICA for Windows, StatSoft Inc., Tulsa (OK), USA, 2013.

Retrieved from: https://www.statsoft.com;

Retrieved on: May 20, 2013

14. M. Wang et al., "The Critical Role of Potassium in Plant Stress Response", Int. J. Mol. Sci., vol. 14, no. 4, pp. 7370 - 7390, Apr. 2013.

DOI: $10.3390 /$ ijms14047370

PMid: 23549270

PMCid: PMC3645691

15. М. Гелев и др, Радиационен мониторинг в района на комплекса физически институти на БАН-7км за периода 1961-2008 2, Институт за ядрени изследвания и ядрена енергетика, София, България, 2009, стр. 3 - 10. (M. Guelev et al., Radiation monitoring in the area of the physical institutes complex of BAS - seventh kilometer for the period 1961 - 2008, Institute for Nuclear Research and Nuclear Energy, Sofia, Bulgaria, 2009, pp. 3-10.)

16. S Chibowski et al., "The examination of the Roztocze region environment. Radioisotope monitoring of soils and plants. The heavy metal content in soil," Pol. J. Environ. Stud., vol. 6, no. 3, pp. 17- 27, 1997.

17. L. Ciuffo et al., "137Cs Soil-to-plant Transfer for Individual Species in a Semi-natural Grassland.
Influence of Potassium Soil Content," J. Rad. Res. vol. 44, no. 3, pp. $277-2830$, Sep. 2003.

DOI: $10.1269 /$ jrr.44.277

18. I. Yordanova et al., "Technogenic Radionuclides in Undisturbed Bulgarian Soils," J. Geochem. Explor. vol. 142, pp. $69-74$, Jul. 2014. DOI: 10.1016/j.gexplo.2014.01.011

19. M. Zhiyanski et al., "Cs-137 distribution in forest floor and surface soil layers from two mountainous regions in Bulgaria," J. Geochem. Explor., vol. 96, no. 2-3, pp. 256 - 266, Feb-Mar. 2008.

DOI: 10.1016/j.gexplo.2007.04.010

20. Р. Котова, В. Бадулин, Р. Тоцева, Ж. Тенев, Г. Иванова, "Изследване на техногенни радионуклиди в обекти от околната среда в района на АЕЦ „Козлодуй“ - 40 - години мониторинг,” в Радиоекологичен мониторинг на работната и жизнената среда, Р. Георгиева, Н. Чобанова, Т. Рангелова, ред., София, България: НЦРРЗ, 2013, стр. 7 - 22. (R. Totseva, V. Badulin, R. Kotova Zh. Tenev, G. Ivanova, "Study of the technogenic radionuclides in environmental projects in the Kozloduy NPP region - 40 years monitoring," in Radioecological monitoring of the working and living environment, R. Georgieva, N. Chobanova, T. Rangelova, Eds., Sofia, Bulgaria: NCRRP, 2013, pp. 7 - 22.)

Retrieved from: http://www.ncrrp.org/new/document1134;

Retrieved on: Jun. 23, 2018 